\title{
Bio-electrochemical denitrification by a novel proton-exchange membrane electrodialysis system - a batch mode study
}

\author{
Dongjin Wan, ${ }^{a, b}$ Huijuan Liu, ${ }^{a *}$ Jiuhui $Q u^{a}$ and Pengju Lei ${ }^{a}$
}

\begin{abstract}
BACKGROUND: Contamination of nitrate in ground and surface water has become an ever-increasing and serious environmental problem. Biological methods hold the promise of converting nitrate into harmless nitrogen. A novel denitrification system which combines proton-exchange membrane electrodialysis with simultaneous bio-electrochemical autotrophic denitrification has been developed. The proton-exchange membrane was used to transfer current and to exclude oxygen or other oxidative chemicals generated in the anode reaction. The $\mathrm{H}_{2}$ generated by the cathode was utilized by autotrophic denitrifying microorganisms in the cathode cell to reduce nitrate. In this study, the transport of $\mathrm{H}^{+}$, a denitrification kinetics model and factors influencing the denitrification rate were explored in batch mode.
\end{abstract}

RESULTS: The addition of $0.03 \mathrm{~mol} \mathrm{~L}^{-1} \mathrm{H}_{2} \mathrm{SO}_{4}$ into the anode cell enhanced proton transport and maintained the pH of the cathode cell in an appropriate range for biological denitrification. The denitrification rate was affected by applied current and biomass. Under adequate current conditions, the kinetics of the denitrification process followed a zero-order kinetics model; the average denitrification rate for unit biomass was calculated to be $9.36 \mathrm{mg} \mathrm{NO}_{3}^{-}-\mathrm{N} \mathrm{VSS} \mathrm{g}^{-1} \mathrm{~h}^{-1}$.

CONCLUSIONS: Results indicate that the system is suitable for denitrification. Owing to its simple structure and operation, it has the potential for use as a system to reduce nitrate in water.

(c) 2010 Society of Chemical Industry

Keywords: bio-electrochemical; denitrification; proton-exchange membrane; electrodialysis; kinetics; nitrite

\section{INTRODUCTION}

Contamination of groundwater and surface water by nitrate is a world-wide and serious problem. ${ }^{1}$ Sources of nitrate in groundwater include fertilizers, industrial, food processing, animal and human wastes. Nitrate has to be removed because nitrate in high concentrations has a detrimental effect on human health and the environment. ${ }^{2}$ The current methods for nitrate removal include ion exchange (IE), ${ }^{3}$ reverse osmosis (RO), catalytic ${ }^{4}$ and biological processes. ${ }^{5-24}$ However, both IE and RO processes cannot transfer nitrate into harmless compounds; they concentrate nitrate from water to brine and require further treatment. High costs and deactivation of catalysts limit the application of catalytic processes. Biological denitrification is an attractive way to convert nitrate into harmless nitrogen with low operating and capital costs. ${ }^{6}$

Hydrogen gas is an ideal electron donor for biological autotrophic denitrification because of its clean nature and low biomass yield, but it has a poor solubility in water $\left(1.6 \mathrm{mg} \mathrm{L}^{-1}\right.$ at $20^{\circ} \mathrm{C}$ ) and is dangerous to control. ${ }^{5-7}$ To overcome the above mentioned problems, the biofilm-electrode reactor (BER), an electrochemical and biological reactor, was first developed by Sakakibara et al. in $1993 . .^{5}$ In this system, hydrogen gas as an electron donor is generated by electrolysis of water. Considerable effort has been made to improve designs for the efficient and economical removal of nitrate from water by a bioelectrochemical method. ${ }^{6-12}$ As anoxic conditions are required for the biodenitrification process, carbon material is usually used as sacrificial anode because of its low oxidative electrode potential; $\mathrm{CO}_{2}$ is formed prior to $\mathrm{O}_{2}$ at low applied voltage. ${ }^{7}$ However, at higher applied voltage, $\mathrm{O}_{2}$ is generated at the anode restricting the denitrification rate. ${ }^{6}$ From this aspect, a multi-electrode system with separators of porous sponge foam rubber between anode and cathode to prevent $\mathrm{O}_{2}$ was developed in 2002. ${ }^{12}$ Since the $\mathrm{pH}$ of the cathode cell increased during electrodialysis, $\mathrm{CO}_{2}$ was used as a buffer to maintain $\mathrm{pH}$ around neutrality in the cathode cell. ${ }^{12}$

Proton-exchange membrane electrodialysis is widely used in the desalination of brackish water and the chlor-alkali industry. ${ }^{25}$ The anode cell and cathode cell are separated by a protonexchange membrane. When a direct current potential is applied between the two electrodes, the positively charged cations move to the cathode, passing through the cation exchange membrane. In 2000, Kiss et al. developed a two-reactor denitrification system containing an electrolysis cell and a packed-bed column. ${ }^{26}$ The

\footnotetext{
* Correspondenceto:Huijuan Liu, State Key Laboratory of Environmental Aquatic Chemistry, Research Center for Eco-Environmental Sciences, Chinese Academy of Sciences, Beijing 100085, China.E-mail: hjliu@rcees.ac.cn

a State Key Laboratory of Environmental Aquatic Chemistry, Research Center for Eco-Environmental Sciences, Chinese Academy of Sciences, Beijing 100085, China
}

b Henan University of Technology, Zhengzhou, Henan 450001, China 
water was first enriched with hydrogen in the cathodic chamber of an electrodialysis cell and then denitrified in the packedbed column, in which granulated activated carbon (GAC) was chosen as bacteria support. In such system, $0.1 \mathrm{~N} \mathrm{H}_{2} \mathrm{SO}_{4}$ was recirculated in the anodic chamber to enhance $\mathrm{H}^{+}$transport, and a cation-permeable membrane was used to transfer current and to block the oxygen generated in the anode reaction. Therefore, $\mathrm{O}_{2}$ generated at the anode could not affect the denitrification rate in the cathode cell, thus avoiding the use of $\mathrm{CO}_{2}$ as buffer. The system was operated at higher applied voltage without $\mathrm{CO}_{2}$ buffer in the cathode cell. However, this denitrification system structure was complex, and the function of the acid added to the anode cell was not discussed in depth. In this study, we developed a novel bioelectrochemical denitrification system based on proton-exchange membrane electrodialysis and simultaneous bio-electrochemical autotrophic denitrification. The suspended bacteria medium was in direct contact with the cathode and thus could utilize $\mathrm{H}_{2}$ conveniently. A suitable concentration of acid was added to the anode cell to enhance proton transport and to keep the $\mathrm{pH}$ of the cathode cell within an appropriate range. The denitrification reaction took place in the cathode cell directly so that the GAC packed-bed wasnot required. The present work proposes this novel system for the first time and discusses its use for nitrate removal from drinking water. The main objectives of this study are (1) to develop the novel proton-exchange membrane electrodialysis system; (2) to evaluate the feasibility of this system; (3) to explore the $\mathrm{H}^{+}$transport law, denitrification kinetics model and factors influencing the system in batch mode.

\section{EXPERIMENTAL MATERIALS AND METHODS}

\section{Experimental setup}

The bio-electrochemical denitrification system used in this study is represented schematically in Fig. 1. The anode cell $(300 \mathrm{~mL}$ volume) and cathode cell ( $400 \mathrm{~mL}$ volume) were separated by a proton-exchange membrane (GEFC-107, GEFC, China); the membrane was located at $5 \mathrm{~mm}$ and $10 \mathrm{~mm}$ distance from anode and cathode, respectively. The cathode was $\mathrm{Cu}$ plate with $36 \mathrm{~cm}^{2}(6 \times 6 \mathrm{~cm})$ effective surface area and the anode was a DSA (dimensionally stable anode) electrode. The suspended autotrophic denitrifying microorganisms were continuously mixed by a recirculation pump in the cathode cell. Direct current was supplied by silicon rectifier (Model DH1718E-4, Beijing Dahua Electronic Instruments Group, Beijing, China). All experiments were conducted at an applied current of 15-100 mA and voltage between the electrodes of $1.5-6.5 \mathrm{~V}$. Before reaction,

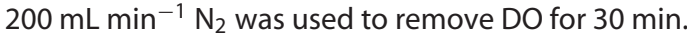

\section{Bacterial inoculation and acclimation}

Bacteria were inoculated from sludge taken from the anoxic section of the $A^{2} / O$ process in the waste-water treatment plant of Qinghe, Beijing. The inoculated culture was incubated in a $2.5 \mathrm{~L}$ closed sealed flask with working volume $2 \mathrm{~L}$, under anoxic conditions using growth medium. The growth medium contained tap water, $\mathrm{NaNO}_{3}\left(\mathrm{NO}_{3}{ }^{-}: 22.58 \mathrm{mg}-\mathrm{N} \mathrm{L}^{-1}\right), \mathrm{KH}_{2} \mathrm{PO}_{4}\left(1 \mathrm{mmol} \mathrm{L}{ }^{-1}\right)$, $\mathrm{K}_{2} \mathrm{HPO}_{4}\left(1 \mathrm{mmol} \mathrm{L}^{-1}\right)$ and $\mathrm{Na}_{2} \mathrm{CO}_{3}\left(1 \mathrm{mmol} \mathrm{L}^{-1}\right)$. The culture was continuously sparged with $100 \mathrm{~mL} \mathrm{~min}^{-1} \mathrm{H}_{2}$. Nitrate, nitrite and biomass concentration were measured on a daily basis. As soon as nitrate degradation was complete, the $2 \mathrm{~L}$ mixture was separated by centrifugation, and then $2 \mathrm{~L}$ of fresh synthetically produced contaminated water, containing microorganisms, tap

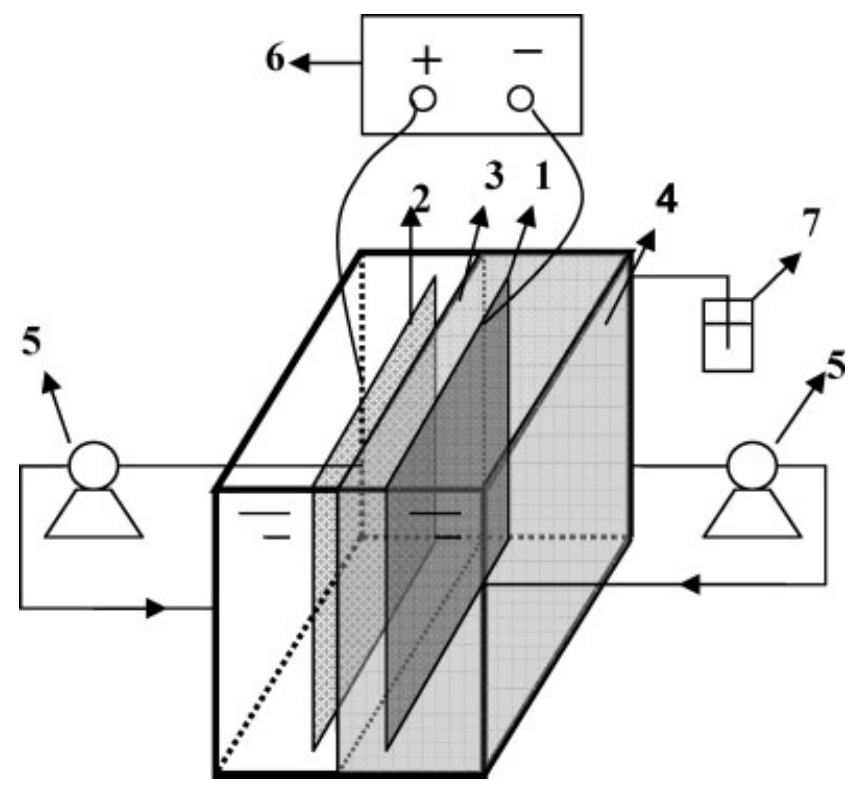

Figure 1. Experimental apparatus: (1) Cu cathode, (2) DSA anode, (3) proton-exchange membrane, (4) suspended bacteria-medium, (5) recirculation pump, (6) DC-power supply, (7) gas outlet.

water, $\mathrm{NaNO}_{3}\left(\mathrm{NO}_{3}{ }^{-}: 22.58 \mathrm{mg}-\mathrm{N} \mathrm{L}^{-1}\right), \mathrm{KH}_{2} \mathrm{PO}_{4}\left(1 \mathrm{mmol} \mathrm{L}{ }^{-1}\right)$, $\mathrm{K}_{2} \mathrm{HPO}_{4}\left(1 \mathrm{mmol} \mathrm{L}^{-1}\right)$ and $\mathrm{Na}_{2} \mathrm{CO}_{3}\left(1 \mathrm{mmol} \mathrm{L}{ }^{-1}\right)$, was added to the flask for complete $\mathrm{H}_{2}$ autotrophic denitrification. This step was repeated for 2 weeks before bio-electrochemical experiments.

\section{Experimental procedure}

First, the acid concentration added to the anode cell to keep the cathode cell $\mathrm{pH}$ neutral was determined through a set of experiments. $\mathrm{pH}$ variations in the cathode cell under $0.01-0.03 \mathrm{~mol} \mathrm{~L}^{-1} \mathrm{H}_{2} \mathrm{SO}_{4}$ supplements in the anode cell were measured during a $3.5 \mathrm{~h}$ electrodialysis process. Experimental details were: applied current $50 \mathrm{~mA}$; electrolyte synthesized by tap water. Microorganisms solution was not added to the cathode cell.

The effect of acid added to the anode cell on the denitrification rate of biomass in the cathode cell was explored. The effect of biomass, applied current and initial nitrate concentration was investigated through batch experiments.

\section{Analytical methods}

The concentrations of $\mathrm{NO}_{3}{ }^{-}-\mathrm{N}$ and $\mathrm{NO}_{2}{ }^{-}-\mathrm{N}$ were determined by ion chromatograph (Metrohm 861, Switzerland). The $\mathrm{pH}$ and ORP (oxidation reduction potential) were measured by multiparameters portable instruments (HACH Sension, USA). VSS (volatile suspended solids) were measured according to standard methods for the examination of water and wastewater. ${ }^{27}$

\section{Kinetics model and principle of the system}

The denitrification process can be simplified into two steps including the consecutive reduction of nitrates to nitrites and then to nitrogen gas, while hydrogen is used as electron donor for denitrification: ${ }^{13}$

$$
\begin{aligned}
& \mathrm{NO}_{3}{ }^{-}+\mathrm{H}_{2} \rightarrow \mathrm{NO}_{2}{ }^{-}+\mathrm{H}_{2} \mathrm{O} \\
& \mathrm{NO}_{2}{ }^{-}+1.5 \mathrm{H}_{2}+\mathrm{H}^{+} \rightarrow 0.5 \mathrm{~N}_{2}+2 \mathrm{H}_{2} \mathrm{O}
\end{aligned}
$$




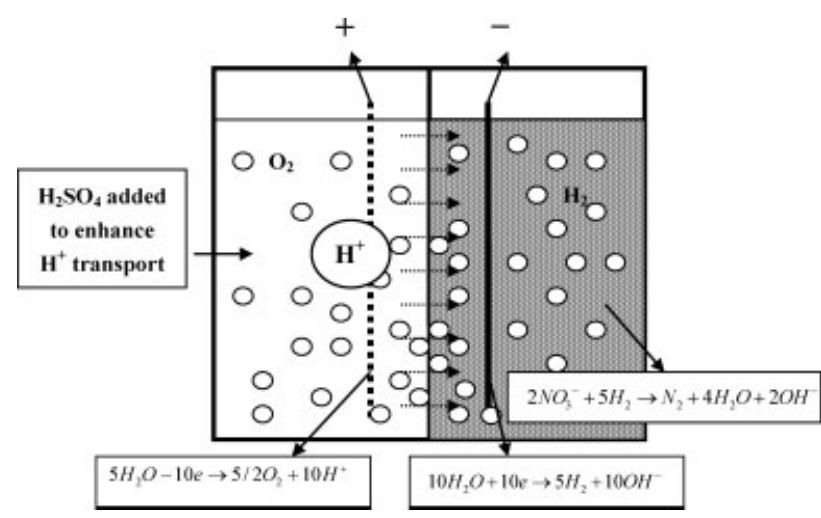

Figure 2. Schematic diagram of proton transport and bioreduction in the proton-exchange membrane electrodialysis system.

The overall reaction is:

$$
\mathrm{NO}_{3}{ }^{-}+2.5 \mathrm{H}_{2}+\mathrm{H}^{+} \rightarrow 0.5 \mathrm{~N}_{2}+3 \mathrm{H}_{2} \mathrm{O}
$$

The kinetics of autotrophic denitrification were expressed in a double Michaelis-Menten (Monod) form and $\mathrm{NO}_{3}{ }^{-}, \mathrm{NO}_{2}{ }^{-}$and $\mathrm{H}_{2}$ were assumed to be the limiting substrates.

The zero-order kinetics based on the Monod model was suitable for non-substrate $\left(\mathrm{H}_{2}\right)$ limiting and low biomass growth yield conditions. The rate at which nitrate is converted to nitrite can be calculated as the first-order overall function of nitrate (zero-order kinetics): $:^{13}$

$$
\frac{d\left[N_{3}{ }^{-}-N\right]}{d t}=-k_{1}\left[N O_{3}{ }^{-}-N\right]^{0}[X]^{1}
$$

and its integration form:

$$
\left[\mathrm{NO}_{3}{ }^{-}-\mathrm{N}\right]_{t}-\left[\mathrm{NO}_{3}{ }^{-}-\mathrm{N}\right]_{0}=-k_{1}[X] t
$$

where $\left[\mathrm{NO}_{3}{ }^{-}-\mathrm{N}\right]_{0}$ and $\left[\mathrm{NO}_{3}{ }^{-}-\mathrm{N}\right]_{t}$ are the initial concentration of nitrate and that at time $t\left(\mathrm{mg}-\mathrm{NO}_{3}{ }^{-}-\mathrm{NL}^{-1}\right),[X]$ is the biomass concentration (VSS $\mathrm{g} \mathrm{L}^{-1}$ ) and $k_{1}$ is the reaction rate constant, specific denitrification rate $\left(\mathrm{mg} \mathrm{NO}_{3}{ }^{-}-\mathrm{N} \mathrm{VSS} \mathrm{g}^{-1} \mathrm{~h}^{-1}\right.$ ).

In previous studies on hydrogenotrophic denitrification, a saturation coefficient of $0.18 \mathrm{mg}-\mathrm{N} \mathrm{L}^{-1}$ was reported for nitrate. ${ }^{13}$ In another study, the reported hydrogen saturation coefficient

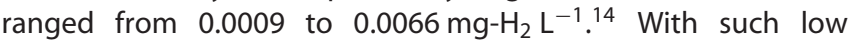
saturation coefficients, it can be assumed that the kinetics of nitrate reduction is independent of nitrate, nitrite and hydrogen concentrations. Nitrate, nitrite and hydrogen concentrations in water treatment systems exceed saturation coefficients, and biomass changes little in batch mode experiment, thus zero-order kinetics can be used in this study.

Figure 2 illustrates the proton transport and bioreduction of nitrate in the proton-exchange membrane electrodialysis system. In this novel system, the proton-exchange membrane was installed between anode and cathode, thus the reactor was divided into two parts: anode cell and cathode cell. The current was carried by protons through the membrane from the anode cell to cathode cell. The oxygen and other oxidative chemicals generated in the anode reaction were excluded from the cathode cell and therefore could not prohibit hydrogenotrophic denitrification.
The hydrogen for denitrification is provided by the cathode reaction:

$$
10 \mathrm{H}_{2} \mathrm{O}+10 e \rightarrow 5 \mathrm{H}_{2}+10 O \mathrm{H}^{-}
$$

For the anode reaction:

$$
5 \mathrm{H}_{2} \mathrm{O}-10 e \rightarrow 5 / 2 \mathrm{O}_{2}+10 \mathrm{H}^{+}
$$

$\mathrm{pH}$ was an important parameter for bio-denitrification. The reported suitable $\mathrm{pH}$ was in the range $7.0-8.0 .^{13,15-18}$ For this electrodialysis process, assuming that there is no separation between anode and cathode, based on $\mathrm{H}^{+}$and $\mathrm{OH}^{-}$balance (Equations (6) and (7)), the $\mathrm{pH}$ of the whole cell will not change. However, compared with the non-separation process, the separation of proton-exchange membrane between anode cell and cathode cell will restrict the proton transport to some extent. Proton transport from anode cell to cathode cell through the proton exchange membrane under the electrical force, and therefore the $\mathrm{H}^{+}$transport efficiency, was restricted by the protonexchange membrane electric transport capacity. If the proton transport efficiency could not balance the $\mathrm{H}^{+}$consumption of electrical dialysis in the cathode cell, the water in the cathode cell will be alkalic, and the denitrification rate will be reduced. Accordingly, a suitable concentration of acid supplement in the anode cell to enhance proton transport is necessary.

\section{RESULTS AND DISCUSSION Effect of acid supplement in anode cell on the pH balance of cathode cell}

As $\mathrm{pH}$ was an important parameter for bioreaction, the concentration of added $\mathrm{H}_{2} \mathrm{SO}_{4}$ in the anode cell to keep the cathode cell $\mathrm{pH}$ in a suitable range (7.0-8.0) was determined through a set of experiments. pH variation in the cathode cell under different concentrations of $\mathrm{H}_{2} \mathrm{SO}_{4}$ in the anode cell is shown in Fig. 3(a). Without acid supplement in the anode cell, the $\mathrm{pH}$ of the cathode cell increased rapidly during the electrodialysis process. After $2.5 \mathrm{~h}$ reaction, owing to inadequate transport of $\mathrm{H}^{+}$, the $\mathrm{pH}$ of cathode cell exceeded 9.5. As shown in Fig. 3(a), acid supplement in the anode cell prevented $\mathrm{pH}$ increasing in the cathode cell effectively, indicating that the dialysis effect of the concentration gradient between the two separate cells could balance the proton transfer restriction of the proton-exchange membrane transport capacity. With the concentration of acid increased from $0.01 \mathrm{~mol} \mathrm{~L}^{-1}$ to $0.03 \mathrm{~mol} \mathrm{~L}^{-1}, \mathrm{pH}$ increase in the cathode cell was better restrained. It was concluded that $0.03 \mathrm{~mol} \mathrm{~L}^{-1}$ was a suitable concentration for added $\mathrm{H}_{2} \mathrm{SO}_{4}$ in the anode cell to keep the $\mathrm{pH}$ of the cathode cell in an appropriate range.

The ORP of the cathode cell was below $-150 \mathrm{mV}$ after $0.5 \mathrm{~h}$ electrodialysis, which meant that the oxygen or other oxidative chemicals generated in the anode reaction were successfully excluded by the proton-exchange membrane and favorable anoxic conditions for denitrification were established in the cathode cell.

The effect of acid supplement in the anode cell on denitrification rate is shown in Fig. 3(b). It can be seen that without acid supplement, the $\mathrm{pH}$ of the cathode cell directly increased due to inadequate proton transport. After $1.5 \mathrm{~h}$ dialysis, the $\mathrm{pH}$ was higher than 9.0, and the denitrification rate was prohibited. From $1.5 \mathrm{~h}$ to $3.5 \mathrm{~h}$, the $\mathrm{pH}$ increased from 9.0 to 10.7 and the removal efficiency increased only from $22.4 \%$ to $28.6 \%$. This phenomena was in accordance with Lee et al.'s study, in which they found that increasing $\mathrm{pH}$ above 8.6 caused a significant decreased 

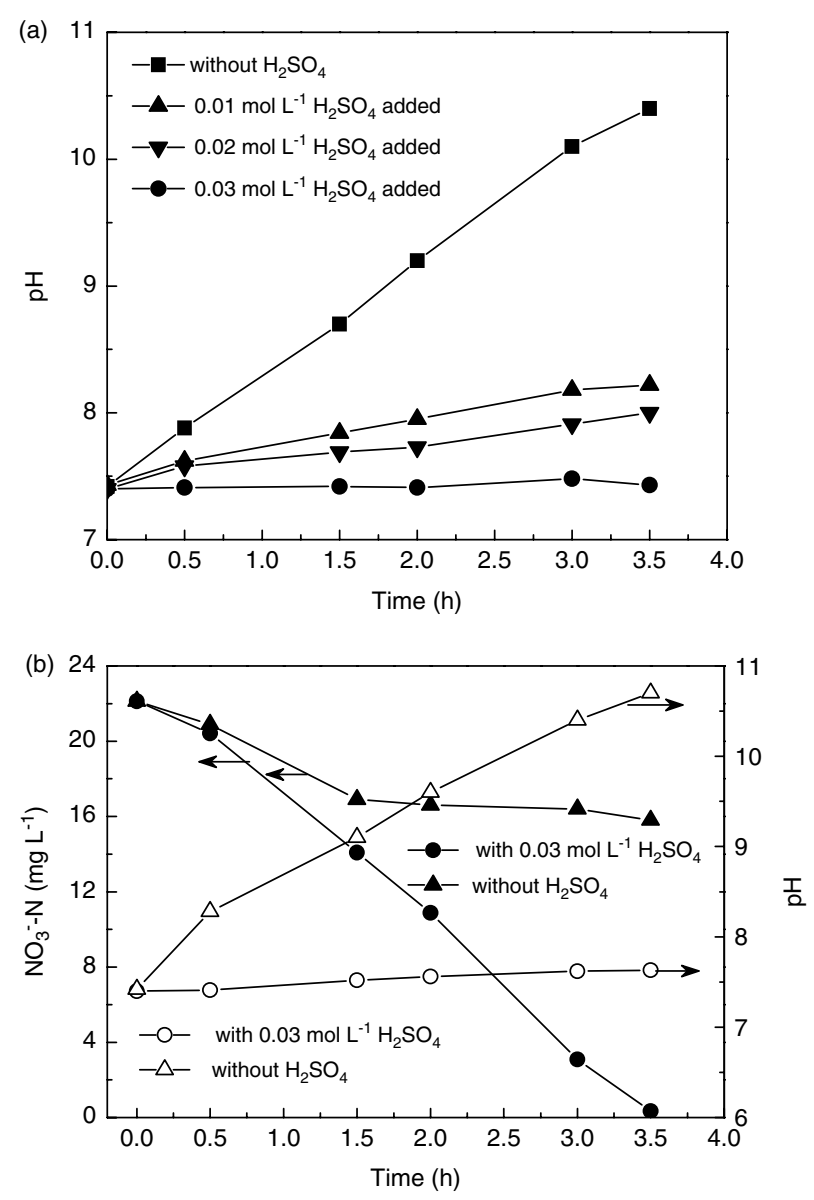

Figure 3. (a) pH variation of cathode cell during electrodialysis process with different acid concentration added in anode cell (applied current $50 \mathrm{~mA}$, acid was added into anode cell, without microorganisms in cathode cell). (b) Effect of acid supplement on denitrification rate in cathode cell: initial $\mathrm{NO}_{3}{ }^{-}-\mathrm{N} 22.13 \mathrm{mg} \mathrm{L}^{-1}$, applied current $50 \mathrm{~mA}$, VSS $0.68 \mathrm{~g} \mathrm{~L}^{-1}$.

in nitrate removal for autohydrogenotrophic denitrification. ${ }^{24}$ Comparatively, with the acid supplement $\left(0.03 \mathrm{~mol} \mathrm{~L}^{-1} \mathrm{H}_{2} \mathrm{SO}_{4}\right)$ in the anode cell, the $\mathrm{pH}$ of the cathode cell remained neutral, indicating that it was favorable for bio-denitrification. After $3.5 \mathrm{~h}$ reaction, nitrate was almost completely reduced by the bioelectrochemical process. The $\mathrm{pH}$ of the cathode cell was 7.65 at the end of reaction, which was slightly higher than the initial $\mathrm{pH}$ 7.34. This was mainly attributed to the denitrification reaction (Equation (3)), $\mathrm{NO}_{3}{ }^{-}$consumes an equal quantity of $\mathrm{H}^{+}$ for complete reduction, resulting in an increase of $\mathrm{pH}$.

\section{Effect of biomass on nitrate removal}

The influence of biomass concentration on nitrate removal was examined and a set of experiments was carried out to determine the kinetics of this system. The original biomass concentrations were $0.05-1.01 \mathrm{~g} \mathrm{~L}^{-1}$, and the initial $\mathrm{NO}_{3}{ }^{-}-\mathrm{N}$ was $22.13-23.13 \mathrm{mg} \mathrm{L}^{-1}$. The results are presented in Fig. 4(a); the required time for complete denitrification was from $23.1 \mathrm{~h}$ to $2.5 \mathrm{~h}$. In heterotrophic denitrification, nitrite accumulation may inhibit the bacterial denitrification rate, ${ }^{17}$ and the inhibitory effect of nitrite was also reported in the autotrophic denitrification process. ${ }^{18}$ In this study, nitrite inhibition was not observed: nitrite appeared as an intermediate product, it was reduced at the end
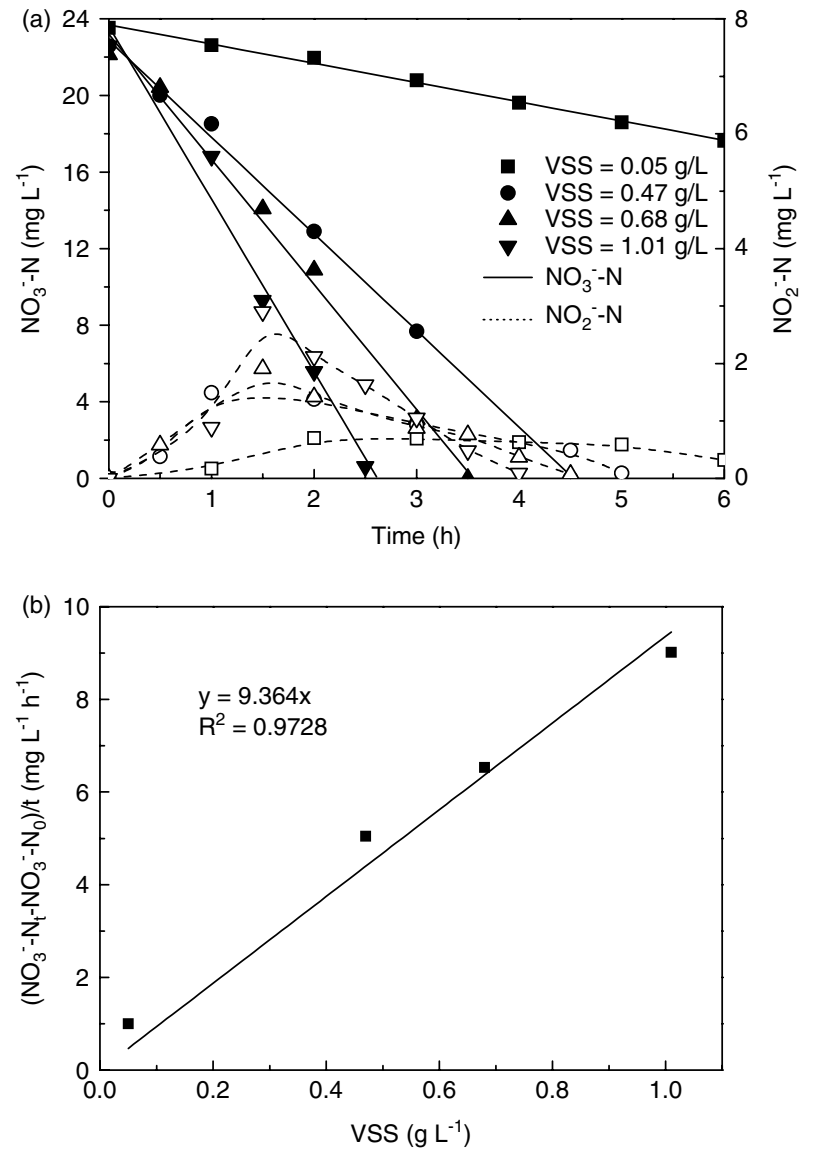

Figure 4. Electrodialysis denitrification (a) of the batch tests in comparison with the Monod model, and correlation (b) between nitrates removed and original biomass concentrations; applied current $50 \mathrm{~mA}$.

\begin{tabular}{|lcccc|}
\hline Table 1. Denitrification kinetic parameters \\
$\begin{array}{l}\text { VSS } \\
\left(\mathrm{g} \mathrm{L}^{-1}\right)\end{array}$ & $\begin{array}{c}\left.\mathrm{CNO}_{3}^{-}-\mathrm{N}\right]_{0} \\
\left(\mathrm{mg} \mathrm{L}^{-1}\right)\end{array}$ & $\begin{array}{c}K^{*}=k_{1} X \\
\left(\mathrm{mg} \mathrm{L}^{-1} \mathrm{~h}^{-1}\right)\end{array}$ & $\begin{array}{c}k_{1}^{*} \\
\left(\mathrm{mg} \mathrm{NO}_{3}{ }^{-}-\right.\end{array}$ \\
\hline 0.05 & 23.13 & 1.00 & 19.70 & 0.9954 \\
0.47 & 22.58 & 5.05 & 10.68 & 0.9980 \\
0.68 & 22.13 & 6.53 & 9.30 & 0.9931 \\
1.01 & 22.48 & 9.02 & 8.70 & 0.9778 \\
\hline$K^{*}:$ obtained by liner fitting for zero-order kinetics. \\
$k_{1}^{*}$ : calculated from experimental data.
\end{tabular}

of reaction, showing that nitrite appears favorable as an electron acceptor.

The zero-order kinetics model used for bio-electrochemical denitrification showed good correlation with the experimental results (Table 1); correlations throughout the experiments were from 0.9778 to 0.9980 , indicating that the applied current $(50 \mathrm{~mA})$ was sufficient for denitrification. A strongly linear relationship $\left(R^{2}=0.9728\right)$ between biomass and denitrification rate was established in this study (Fig. 4(b)). In this process, the nitrate reduction rate was in the range $8.70-19.70 \mathrm{mgNO}_{3}{ }^{-}-\mathrm{N} \mathrm{g}^{-1} \mathrm{VSSh}^{-1}$ (0.21-0.47 $\mathrm{gNO}_{3}{ }^{-}-\mathrm{N} \mathrm{g}^{-1} \mathrm{VSS} \mathrm{d}^{-1}$ ) for $20 \pm 1{ }^{\circ} \mathrm{C}$, and the average denitrification rate for unit biomass was calculated to be 9.36 $\mathrm{mgNO}_{3}{ }^{-}-\mathrm{N} \mathrm{g}^{-1} \mathrm{VSS} \cdot \mathrm{h}^{-1}$. The kinetics of hydrogen autotrophic 
Table 2. Comparision between hydrogen autotrophic denitrification rates

\begin{tabular}{|c|c|c|c|c|c|}
\hline Method of hydrogen supply & Biomass $\mathrm{g} \mathrm{L}^{-1}$ & Temp. ${ }^{\circ} \mathrm{C}$ & $\mathrm{pH}$ & $v_{\max } \mathrm{g} \mathrm{NO}_{3}-\mathrm{N} \mathrm{VSS} \mathrm{g}^{-1} \mathrm{~d}^{-1}$ & Reference \\
\hline Direct & $1.5-2.5$ & 30 & 7.5 & $0.22-0.37$ & 13 \\
\hline Direct & 0.5 & $25 \pm 1$ & $7.5-9.5$ & $0.38-0.74$ & 19 \\
\hline Direct & 0.5 & $12 \pm 1$ & $7.5-9.5$ & $0.21-0.28$ & 19 \\
\hline Electrodialysis & $0.05-1.01$ & $20 \pm 1$ & $7.05-7.20$ & $0.21-0.47$ & This study \\
\hline
\end{tabular}

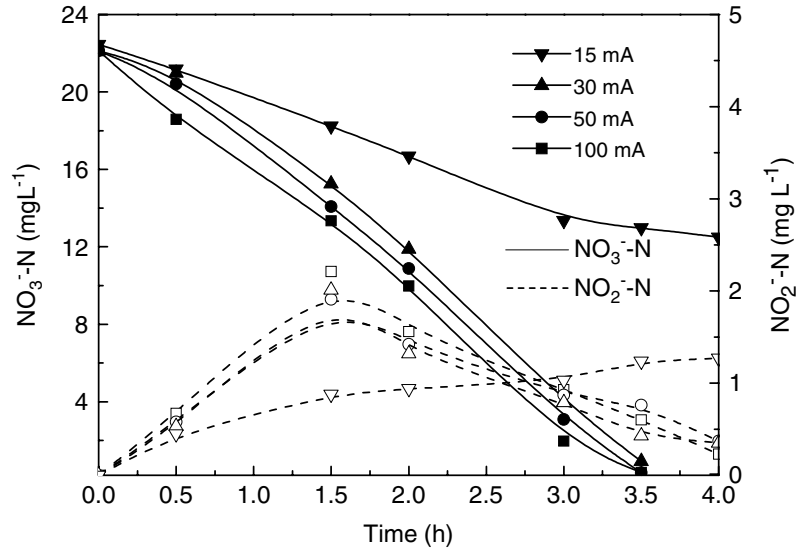

Figure 5. Electrical current effect on nitrate removal, VSS $0.68 \mathrm{~g} \mathrm{~L}^{-1}$.

denitrification has been studied in recent years and some research has provided denitrification rates. ${ }^{13,19}$ A comparison between these studies is summarized in Table 2; it can be concluded that the microorganism in this novel system achieved the same denitrification rate as directly supplied hydrogen for nitrate reduction. That is, this novel system could provide satisfactory conditions for hydrogenotrophic microorganisms. The slight difference between denitrification rates was mainly due to mixed culture inoculation and acclimation differences. Compared with directly supplied hydrogen, this novel method resolves the problem of hydrogen supply and is easily controlled for safety.

\section{Effect of electrical current on nitrate removal}

In the electrodialysis process, the rate of donor $\left(\mathrm{H}_{2}\right)$ supply was affected by the electrical current. The function of the electrical current in the denitrification process was explored in this study. The original biomass concentration was $0.68 \mathrm{~g} \mathrm{~L}^{-1}$, and the applied current was varied from $15 \mathrm{~mA}$ to $100 \mathrm{~mA}$. Variations of nitrate and nitrite concentration during denitrification process are presented in Fig. 5.

According to Faraday's law, the effective current could be defined as:

$$
\begin{aligned}
I_{E}=[ & \left.\left(C_{\mathrm{NO}_{3}{ }^{-}, \text {initial }}-C_{\mathrm{NO}_{3}{ }^{-}, t}\right) \times 5+\left(C_{\mathrm{NO}_{2}{ }^{-}, \text {initial }}-C_{\mathrm{NO}_{2}-, t}\right) \times 3\right] \\
& \times F \times V / T
\end{aligned}
$$

where $C$ is nitrate or nitrite concentration $\left(\mathrm{mmol}-\mathrm{NL}^{-1}\right.$ ), $F$ is Faraday's constant $\left(26.8 \mathrm{~mA} \mathrm{~h} \mathrm{mmol}^{-1}\right), V$ is the cathode cell effective volume $(\mathrm{L})$ and $T$ is reaction time (h).

If an initial nitrate concentration of $22.58 \mathrm{mg}^{-N^{-1}}$ can be completely reduced in $3.5 \mathrm{~h}$, the effective current is calculated as $24.7 \mathrm{~mA}$, which was the minimum current supplied based on the hypothesis that the electric current efficiency reached
$100 \%$. As shown in Fig. 5, denitrification rate was not affected by currents between 30 and $100 \mathrm{~mA}$. In the high current supply condition $(I \geq 30 \mathrm{~mA})$, the bulk solution in the cathode cell was saturated with $\mathrm{H}_{2}$ generated by the cathode, and the removal rate was not affected by the rate of donor supply. The removal rate reached $96.0 \%, 98.5 \%$ and $98.4 \%$ for $30 \mathrm{~mA}, 50 \mathrm{~mA}$ and $100 \mathrm{~mA}$ after $3.5 \mathrm{~h}$ electrodialysis, respectively. Meanwhile, the kinetics of denitrification attributed to zero-order reduction under this non-substrate $\left(\mathrm{H}_{2}\right)$ limiting condition. When the current became lower $(15 \mathrm{~mA})$, the denitrification rate was reduced because of inadequate $\mathrm{H}_{2}$ supply, the removal rate was only $42.5 \%$ after $3.5 \mathrm{~h}$ electrodialysis, showing that the hydrogen generated by the electrodialysis process was not sufficient for bio-denitrification. Consequently, the kinetics did not fit the zero-order kinetics model and nitrite was accumulated under this substrate $\left(\mathrm{H}_{2}\right)$ limiting condition. At the end of the reaction, nitrite concentration increased to $1.27 \mathrm{mg}-\mathrm{N} \mathrm{L}^{-1}$. The corresponding current efficiency reached $70 \%$ at $5 \mathrm{~mA}, 80 \%$ at $30 \mathrm{~mA}, 48 \%$ at $50 \mathrm{~mA}$ and $24 \%$ at $100 \mathrm{~mA}$. From both economic and removal efficiency aspects, $30 \mathrm{~mA}$ was the most suitable current for nitrate removal.

In the BER system of non-separation between anode and cathode, the reported maximum applied voltage was $5.0 \mathrm{~V}$. Higher applied voltages did not bring an increase of nitrate and nitrite removal. ${ }^{6}$ The maximum nitrate removal rate was $5.68 \mathrm{mg}$ $\mathrm{NL}^{-1}$ and the corresponding HRT was $1.2 \mathrm{~h} .{ }^{6}$ In this study, this novel system removed $22.13 \mathrm{mg}-\mathrm{N} \mathrm{L}^{-1} \mathrm{NO}_{3}{ }^{-}$in $3.5 \mathrm{~h}$ with biomass of $0.68 \mathrm{~g} \mathrm{~L}^{-1}$; a high applied voltage of $6.5 \mathrm{~V}$ (corroponding current $100 \mathrm{~mA}$ ) did not affect denitrification rate. The time required for complete denitrification could be made even shorter through increased biomass (Fig. 4). It can be concluded that this novel system could be operated under higher applied current and biomass concentration, and thus could provide a higher removal rate.

\section{Effect of initial nitrate concentration on nitrate removal}

The effect of initial nitrate concentration on nitrate removal was explored with initial nitrate concentration fixed at 22.13, 15.76 and $11.31 \mathrm{mg} \mathrm{L}^{-1}$. Nitrate removal was modeled according to a zero-order kinetics model and the results are presented in Fig. 6 and Table 3. A highly linear relationship $\left(R^{2}>0.97\right)$ between nitrate concentrations and time confirmed that the denitrification process could be well described by the Monod equation. It was indicated that the hydrogen generated by the cathode was enough for bioreduction. Nitrite also appears to be a favorable electron acceptor and it took about $0.5-1.0 \mathrm{~h}$ longer than nitrate for complete reduction.

\section{CONCLUSION}

The feasibility of bio-electrochemical denitrification by protonexchange membrane electrodialysis was demonstrated in this 

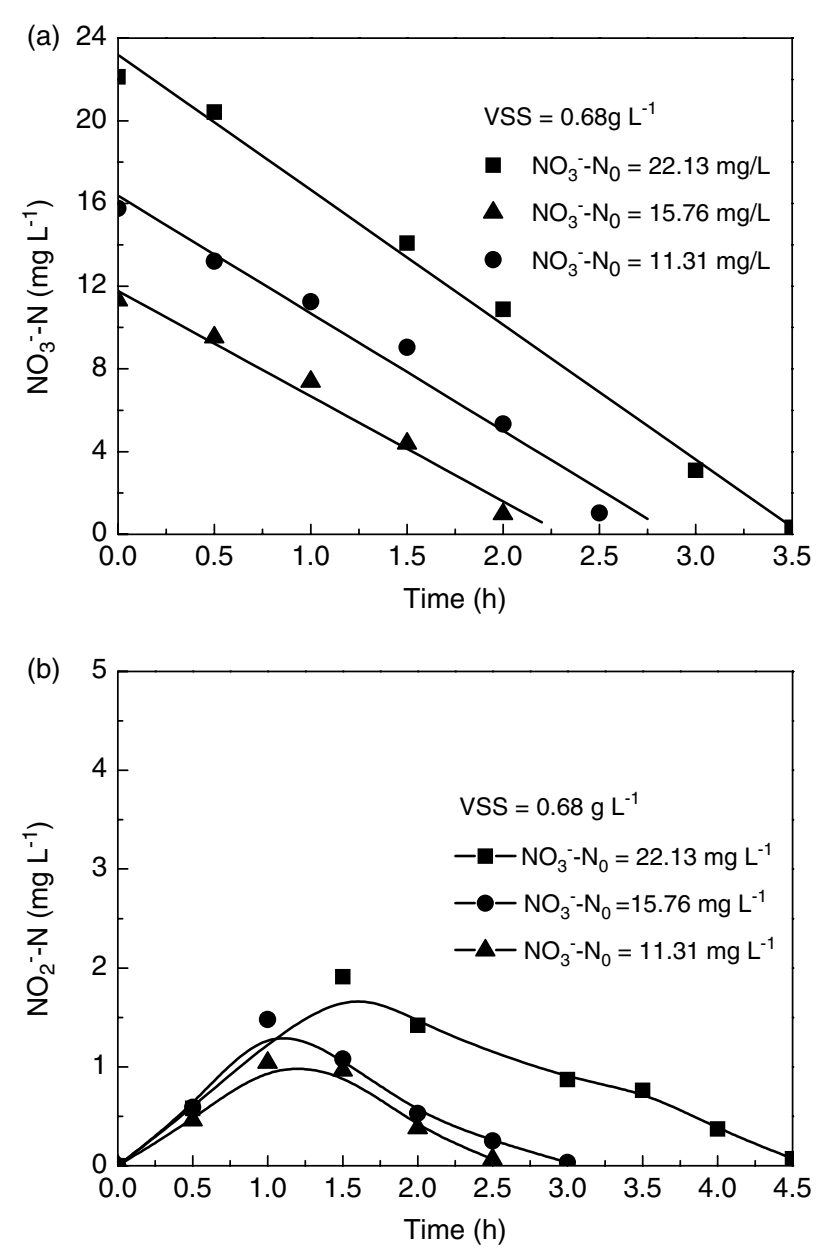

Figure 6. Initial nitrate concentration effect on (a) nitrate removal, (b) nitrite generation; $\mathrm{VSS}=0.68 \mathrm{~g} \mathrm{~L}^{-1}$, applied current $50 \mathrm{~mA}$.

\begin{tabular}{|c|c|c|c|}
\hline $\begin{array}{l}\mathrm{C}\left[\mathrm{NO}_{3}{ }^{-}-\mathrm{N}\right]_{0} \\
\left(\mathrm{mg} \mathrm{L}^{-1}\right)\end{array}$ & $\begin{array}{c}K=k_{1} X \\
\left(\mathrm{mg} \mathrm{L}^{-1} \mathrm{~h}^{-1}\right)\end{array}$ & $\begin{array}{c}k_{1} \\
\left(\mathrm{mgNO}_{3}{ }^{-}-\mathrm{NVSS} \mathrm{g}^{-1} \mathrm{~h}^{-1}\right)\end{array}$ & $R^{2}$ \\
\hline 22.13 & 6.52 & 9.58 & 0.9931 \\
\hline 15.76 & 5.36 & 7.88 & 0.9721 \\
\hline 11.31 & 5.08 & 7.47 & 0.9783 \\
\hline
\end{tabular}

study. The $\mathrm{pH}$ of the cathode cell remained neutral during the electrodialysis process by adding $0.03 \mathrm{~mol} \mathrm{~L}^{-1} \mathrm{H}_{2} \mathrm{SO}_{4}$ into the anode cell. Autotrophic denitrifying microorganisms in the cathode cell utilized $\mathrm{H}_{2}$ generated by the cathode to reduce nitrate. The denitrification rate of this system was affected by the applied current and biomass. The kinetics of the denitrification process followed a zero-order kinetics model for sufficient current, and the average denitrification rate for unit biomass was calculated to be $9.36 \mathrm{mgNO}_{3}{ }^{-}-\mathrm{N} \mathrm{VSS} \mathrm{g}^{-1} \cdot \mathrm{h}^{-1}$. From the results of experiments, we can conclude that this is a novel bio-electrochemical system for denitrification that could be operated without any buffer in the cathode cell, and simultaneously avoids oxidative chemical prohibition of the anode cell. This method can serve as an attractive solution for nitrate treatment.

\section{ACKNOWLEDGEMENTS}

This work was supported by the National High Technology Research and Development Program of China (Grant No. 2006AA06Z302).

\section{REFERENCES}

1 Nolan BT, Ruddy BC, Hitt KJ and Helsel DR, Risk of nitrate in groundwaters of the United States - a national perspective. Environ Sci Technol 31:2229-2236 (1997).

2 Kleinjans JC, Albering HJ, Marx A, Van Maanen JM, Van Agen B and Ten Hoor F, et al, Nitrate contamination of drinking water: evaluation of genotoxic risk in human population. Environ Health Persp 94:189-193 (1991).

3 Samatya S, Kabay N, Yüksel Ü, Arda M and Yüksel M, Removal of nitrate from aqueous solution by nitrate selective ion exchange resins. React Funct Polym 66:1206-1214 (2006).

4 Prüsse U, Hähnlein M, Daum J and Vorlop K-D, Improving the catalytic nitrate reduction. Catal Today 55:79-90 (2000).

5 Sakakibara $Y$ and Kuroda M, Electric prompting and control of denitrification. Biotechnol Bioeng 42:535-537 (1993).

6 Wan DJ, Liu HJ, Qu JH, Lei PJ, Xiao SH and Hou YN, Using the combined bioelectrochemical and sulfur autotrophic denitrification system for groundwater denitrification. Bioresource Technol 100:142-148 (2009).

7 Wang $\mathrm{HY}$ and $\mathrm{QuJH}$, Combined bioelectrochemical and sulfur autotrophic denitrification for drinking water treatment. Water Res 37:3767-3775 (2003).

8 Szekeres S, Kiss I, Bejerano TT and Soares Ml, Hydrogen-dependent denitrification in a two-reactor bio-electrochemical system. Water Res 35:715-719 (2001).

9 Feleke Z, Arakf K, Sakakibara Y, Watanabe T and Kuroda M, Selective reduction of nitrate to nitrogen gas in a biofilm-electrode reactor. Water Res 32:2728-2734 (1998).

10 Sakakibara Y and Nakayama T, A novel multi-electrode system for electrolytic and biological water treatments: electric charge transfer and application to denitrification. Water Res 35:768-778 (2001).

11 Feleke $Z$ and Sakaibara Y, A bio-electrochemical reactor coupled with adsorber for the removal of nitrate and inhibitory pesticide. Water Res 36:3092-3102 (2002).

12 Prosnansky M, Sakaibara $Y$ and Kuroda M, High-rate denitrification and SS rejection by biofilm-electrode reactor (BER) combined with microfiltration. Water Res 36:4801-4810 (2002).

13 Kurt M, Dunn Jl and Bourne RJ, Biological denitrification of drinking water using autotrophic organisms with $\mathrm{H}_{2}$ in a fluidized-bed biofilm reactor. Biotechnol Bioeng 29:493-501 (1987).

14 Smith RL, Ceazan ML and Brooks MH, Autotrophic, hydrogenoxidizing, denitrifying bacteria in groundwater, potential agents for bioremediation of nitrate contamination. Appl Environ Microbiol 60:949-955 (1994)

15 Mateju V, Cizinska S, Krejci J and Janoch T, Biological water denitrification, a review. Enzyme Microbiol Technol 14:170-182 (1992).

16 Haugen KS, Semmens MJ and Novak PJ, A novel in situ technology for the treatment of nitrate contaminated groundwater. Water Res 36:3497-3506 (2002)

17 Almeida JS, Reis MAM and Carrondo MJT, Competition between nitrate and nitrite reduction in denitrification by pseudomonas fluorescens. Biotechnol Bioeng 46:476-484 (1995).

18 Oh SE, Kim KS, Choi HC, Cho J and Kim IS, Kinetics and physiological characteristics of autotrophic denitrification by denitrifying sulfur bacteria. Water Sci Technol 42:59-68 (2000).

19 Rezania B, Cicek N and Oleszkiewicz JA, Kinetics of hydrogendependent denitrification under varying $\mathrm{pH}$ and temperature conditions. Biotechnol Bioeng 92:900-906 (2005).

20 Vasiliadou IA, Siozios S, Papadas IT, Bourtzis K, PavlouS and Vayenas DV, Kinetics of pure cultures of hydrogen-oxidizing denitrifying bacteria and modeling of the interactions among them in mixed cultures. Biotechnol Bioeng 95:513-525 (2006).

21 Vasiliadou IA, Pavlou S and Vayenas DV, A kinetic study of hydrogenotrophic denitrification. Process Biochem 41:1401-1408 (2006).

22 Hiscock KM, Lloyd JW and Lerner DN, Review of natural and artificial denitrification of groundwater. Water Res 25:1099-1111 (1991). 
23 Germonpre J, Verstraete L and Beenearte W, Methylotrophic and hydrogenotrophic denitrification at the Blankaart plant. Water Supply 10:53-64 (1992).

24 Lee K-C and Rittmann BE, Effects of $\mathrm{pH}$ and precipitation on autohydrogenotrophic denitrification using the hollow-fiber membrane-biofilm reactor. Water Res 37:1551-1556 (2003).

25 Nalan K, Özgür A, Saba S, Ümran $Y$ and Mithat $Y$, Separation of fluoride from aqueous solution by electrodialysis: effect of process parameters and other ionic species. J Hazard Mater 153:107-113 (2008)
26 Kiss I, Szekeres S, Bejerano TT and Soares MIM, Hydrogen-dependent denitrification: preliminary assessment of two bio-electrochemical systems. Water Sci Technol 42:373-379 (2000).

27 APHA, AWWA, and WPCF, Standard Methods for the Examination of Water and Wastewater, 17th edn. American Public Health Association, American Water Works Association and Water Pollution Control Federation Washington, DC (1989). 